\title{
Incidence of posterior capsule opacification following the implantation of a foldable hydrophilic acrylic intraocular lens: a 4 year follow-up study
}

\author{
Incidência da opacificação da cápsula posterior após o implante de uma lente intraocular acrílica \\ hidrofílica dobrável: seguimento de 4 anos
}

Priscilla de Almeida Jorge ${ }^{1}$, Delano Jorge ${ }^{2}$, Camila Vieira Ventura ${ }^{3}$, Bruna Vieira Ventura ${ }^{3}$, Wagner Lira ${ }^{3}$, Marcelo Carvalho Ventura ${ }^{3}$, Marcony Rodrigues Santhiago ${ }^{1}$, Newton Kara-Junior ${ }^{1}$

\begin{abstract}
Purpose: To evaluate the incidence of posterior capsule opacification (PCO) four years after the implantation of a hydrophilic acrylic intraocular lens (IOL).

Methods: Fifty-eight randomly selected eyes from 58 patients were analyzed four years after phacoemulsification and loflex IOL implantation. The patients underwent an ophthalmic examination to detect PCO and a detailed medical history was obtained. The patients' charts were reviewed for their corrected distance visual acuity prior to the IOL implantation, as well as for one month postoperatively. The Student's t-test was used for statistical analysis.

Results: The mean age of patients without PCO was $74.6 \pm 9.5$ years, compared to $70.3 \pm 15$ years in patients with $P C O$. Four years after surgery, 39 of the 58 eyes (67\%) had detectable PCO and 24 eyes (41.3\%) had decreased visual acuity (VA) due to PCO. These patients were referred for Nd:YAG laser capsulotomy. Three patients (5.1\%) had decreased VA due to glaucoma, IOL opacification, or age-related macular degeneration. Twelve eyes (20.7\%) presented mild PCO with unchanged VA. Systemic arterial hypertension was reported by $45 \%$ of the patients, and in 3.5\% of these cases this was associated with diabetes mellitus.

Conclusion: This study found the incidence of PCO to be $67 \%$ four years after phacoemulsification and loflex IOL implantation.
\end{abstract}

Keywords: Posterior capsule of the lens; Capsule opacification; Postoperative complications; Cataract/epidemiology; Visual acuity

\section{RESUMO}

Objetivo: Avaliar a incidência da opacificação da cápsula posterior com o implante de uma lente intraocular acrílica hidrofilica.

Métodos: Cinquenta e oito olhos, de 58 pacientes, selecionados de forma aleatória, foram examinados 4 anos após a cirurgia de facoemulsificação com implante da lente intraocular loflex em uma campanha comunitária para pessoas carentes. Os pacientes foram submetidos ao exame oftalmológico a fim de detectar opacificação da cápsula posterior. Foi obtido histórico médico detalhado. A acuidade visual corrigida antes e 1 mês após a cirurgia foi obtida através de revisão em prontuário médico. $O$ teste t de student foi utilizado para a análise estatística.

Resultados: Aidade média dos pacientes sem opacificacão da cápsula posterior fol $74,6 \pm 9,5$ anos, e 70,3 \pm 15 anos nos pacientes com opacificação da cápsula posterior. Após 4 anos da cirurgia, 39 olhos (67\%) foram diagnosticados com opacificação da cápsula posterior, e 24 olhos (41,3\%) tiveram redução da acuidade visual causada pela opacificação da cápsula posterior, sendo encaminhados para realização de capsulotomia com Nd:YAG laser. Trêsolhos (5,1\%) tiveram redução da acuidade visual causada por glaucoma, opacificação da lente intraocular e degeneração macular relacionada à idade. Em outros 12 olhos (20,7\%) que apresentaram opacificação da cápsula posterior, a acuidade visual ficou mantida. Dentre as doenças sistêmicas, a hipertensão arterial foi relatada por $45 \%$ da amostra avaliada e 3,5\% referiram diabetes mellitus. Conclusão: O estudo encontrou incidência de 67\% de opacificação da cápsula posterior na lente intraocular loflex 4 anos após a cirurgia.

Descritores: Cápsula posterior do cristalino; Opacificação da cápsula; Complicações pós-operatórias; Catarata/epidemiologia; Acuidade visual

\section{INTRODUCTION}

Posterior capsule opacification (PCO) is one of the most common postoperative complications following cataract surgery ${ }^{(1,2)}$. It usually leads to a decrease in visual acuity (VA), a loss of contrast sensitivity, and glare disability. It also precludes examination of the posterior segment ${ }^{(3)}$. Patients who have visual function reduction in response to PCO may be treated with Neodymium (Nd):YAG laser capsulotomy to restore VA, but this treatment is not free of complications ${ }^{(1,4)}$.

Researchers are trying to identify the key factors in reducing the incidence of $P\left(O^{(5,6)}\right.$. It has already been demonstrated that sharp-edged intraocular lens (IOL) optics are preferable to round-edged IOL optics ${ }^{(7)}$. Modification of the IOL surface, which can inhibit cell and protein adhesion, has been suggested for reducing the incidence PCO ${ }^{(4)}$. Furthermore, modifications of $\mathrm{IOL}$ design, maintaining an open capsular bag, enhancing the aqueous endocapsular inflow, and even the use of a bag-in-the-lens technique, all appear to prevent capsular bag opacification ${ }^{(8,9)}$

The causes of opacification include cell proliferation and migration, epithelial-to-mesenchymal cell transitions, collagen deposition, and lens fiber regeneration of lens epithelial cells ${ }^{(10)}$. The main factors relating to PCO development are either patient related (e.g., the age and type of ocular disease), surgery related (e.g., the capsulorrhexis size, and whether irrigation/aspiration of the capsule, a hydrodissection-enhanced cortical clean-up, sealed capsule irrigation, and in-the-bag IOL fixation, are performed), and IOL related (material and design of the implanted $I O L)^{(8,10-12)}$. The loflex (Mediphacos) is a 1-piece foldable acrylic hydrophilic IOL for posterior chamber implantation, designed with square edges for PCO prevention. It has a low cost and 
has been marketed for over ten years in several European, Asian, and Latin American countries. Its postoperative performance has not yet been studied. Thus, this study aimed to evaluate the incidence of PCO four years after loflex IOL implantation.

\section{METHODS}

A sample of 150 eyes was randomly selected. This sample size calculation was based on the PCO incidence reported in the literature. The patients were from a population that had undergone cataract surgery and loflex IOL implantation in 2007, as part of a community campaign for underprivileged people. A total of 50 eyes (31 patients) could not be located, either due to communication difficulties relating to geographical distance, or to patient death. Of the 100 eyes located, 13 were not presented for examination. Thus, 87 eyes corresponding to 58 patients, were available for examination. However, to avoid bias, in patients who underwent cataract surgery in both eyes, only the right eye was included in the study. Therefore, a final total of 58 eyes from 58 patients were submitted to a detailed ophthalmic examination.

The inclusion criteria comprised being subjected to phacoemulsification and Ioflex IOL implantation between January and June 2007. The exclusion criteria comprised intraoperative complications, such as posterior capsule rupture, and non-loflex IOL implantation. The same surgeon performed all surgical procedures using a Universal II Phacoemulsifier (Alcon). In each case a $2.8 \mathrm{~mm}$ incision was made under peribulbar anesthesia, using balanced salt solution (BSS ${ }^{\oplus}$, Alcon) and $2 \%$ methylcellulose viscoelastic (Ophthalmos). Identical continuous curvilinear capsulorrhexis and cortical clean-up procedures were used in all cases. The ophthalmic examination included measurements of corrected distance visual acuity (CDVA) and biomicroscopy slit lamp evaluations after pupil dilation with Mydriacyl (Alcon). Patients with a VA decreased in response to PCO were referred to $\mathrm{Nd}$ :YAG laser treatment. A detailed medical history for each patient was also obtained. The patients' charts were reviewed for their CDVA prior to IOL implantation as well as for one month postoperatively.

This study was approved by an Ethics Committee (CEP: 054/2011) and followed the Declaration of Helsinki principles. The variables were expressed as the mean and standard error of the mean. We used the Student's t-test for independent samples to check for possible differences in VA, and the Student's t-test for paired samples to analyze the mean VA of patients with and without PCO during the evaluation periods. A $p$ value of $<0.05$ was adopted for rejection of the null hypothesis.

\section{RESULTS}

Of the 58 patients, 27 were male and 31 female. The mean age of patients without PCO in the four year follow-up period was $74.6 \pm 9.5$ years, and the mean age of patients with PCO over the same period was $70.3 \pm 15.1$. There was no statistically significant difference between the mean age of the patients with or without PCO $(p=0.182)$. All surgeries were uneventful both intra and postoperatively.

There was no statistically significant difference between the mean VA of the patients with or without PCO during the evaluation period. Preoperative CDVA ranged from hand movement to 0.30 logMAR. One month after cataract surgery with Ioflex IOL implantation, improvement of VA was observed in all but two patients. These two patients either had glaucoma or an age-related macular degeneration. On systemic disease evaluation, 45\% (26 patients) reported systemic arterial hypertension and 3.5\% (2 patients) had diabetes mellitus.

Four years after surgery, 39 out of 58 patients (67\%) had PCO as detected by a slit lamp examination. Of the total, 24 eyes (41.3\%) had decreased VA due to PCO and were referred for Nd:YAG laser capsulotomy (Figure 1). Three eyes (5.1\%) had decreased VA due to glaucoma, IOL opacification, and age-related macular degeneration,

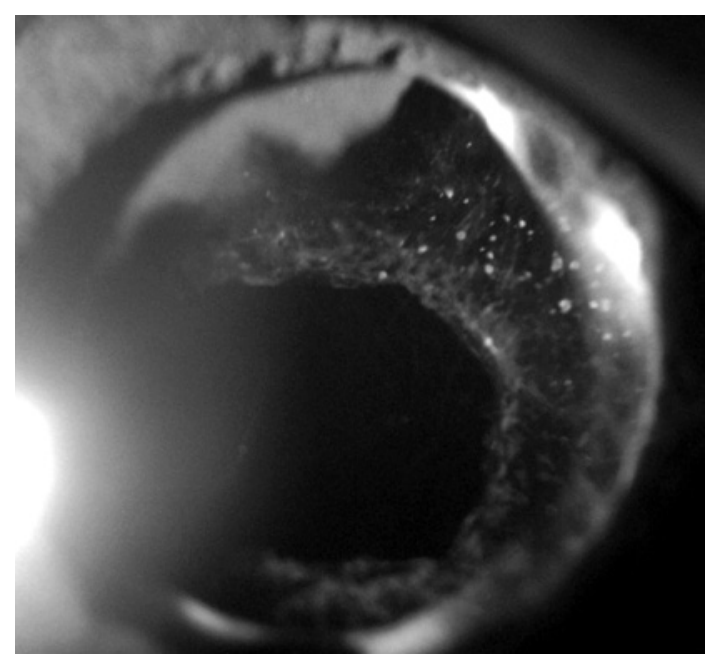

Figure 1. Posterior capsulotomy with Nd:YAG laser.

respectively. In a further 12 eyes (20.7\%) with mild PCO, VA remained unchanged.

\section{DISCUSSION}

This study aimed to evaluate the PCO rates in Ioflex IOLs four years after surgery. We found that $67 \%$ of patients suffered from this postoperative complication. Clinical studies have shown varied incidences of PCO for other hydrophilic IOLs, ranging from $4.6 \%$ to $50 \%{ }^{(1,13-15)}$. Notably, all of these incidence rates are less than the one we have found. To our knowledge, there are no other published studies that have reported the incidence of PCO in the loflex IOL. As the eradication of PCO is a major goal of researchers working to improve IOL materials and design, as well as surgical techniques ${ }^{(6,10,16)}$, it is important that additional research is performed.

The IOL material and design is able to influence the incidence of $P C O^{(5,7,8)}$. It has been well documented that a hydrophobic lens material causes less PCO than a hydrophilic material, even though the latter is more uveal biocompatible ${ }^{(17,18)}$. However, PCO may progresses significantly with time and is more extensive following polymethylmetacrylate IOL implantation, while its progression rate after silicone and acrylic IOL implantation is low ${ }^{(19)}$.

Previous reports have shown that hydrophilic IOLs lead to at least twice the number of Nd:YAG laser treatments when compared with hydrophobic lenses ${ }^{(1,13,17,18)}$. Although Nd:YAG laser capsulotomy is the standard treatment for PCO and is generally found to be safe and effective, it is also expensive and not free of complications ${ }^{(1,11,20)}$, including a significant rate of morbidity from postoperative complications. The most common complication is intraocular pressure elevation, while other complications include cystoid macular edema, retinal hemorrhage or detachment, iritis, vitreous prolapse, corneal damage, vitritis, iris damage, pupillary blockage, hyphema, IOL subluxation, and localized exacerbation of endophthalmitis(21,22). PCO is also associated with socioeconomic factors, since an outpatient examination is required to diagnose it and, depending on local policies, an additional hospital visit may be required for Nd:YAG laser treatment ${ }^{(23)}$. All of these factors emphasize the importance of efforts aimed at minimizing Nd:YAG laser capsulotomy necessity.

Following technological advances, IOL design has been modified from round-edged to square-edged, and this has resulted in a reduction in the incidence of $\mathrm{PCO}^{(24)}$. However, studies suggest that square-edged IOLs should completely encompass the 360 degrees around the IOL optic in order to provide an effective barrier ${ }^{(25)}$. Furthermore, another study has shown differences between brands of square-edged len- 
ses, and suggested that variations in their edge profiles may account for clinical differences in postoperative PCO rates ${ }^{(26)}$. In addition, it has been reported that acrylic IOLs appear to lose their PCO preventive effect, despite their sharp optic edges ${ }^{(27)}$.

Although the loflex is a 1-piece lens, this not considered to be a factor in the development of PCO, since both 1- and 3-piece IOLs have been studied to evaluate their influence on PCO formation and no statistically significant differences between them have been found $(28,29)$.

PCO is also age-dependent, being more frequently observed as a postoperative complication in young people and children ${ }^{(7,30)}$. This study evaluated an adult population and thus did not find a statistically significant difference on the independent analysis of age between patients with and without PCO.

Decreased VA induced by PCO was noted in $41 \%$ of patients. This value is supported by data in the published literature, and confirms that it represents the most frequent cause of vision reduction following cataract surgery ${ }^{(7,15)}$. Only one patient presented IOL opacification, but we had previously reported, in another study with the same $\mathrm{IOL}$, an incidence as high as $7 \%$ of long term IOL opacification, with no correlation to $\mathrm{PCO}^{(16)}$.

\section{CONCLUSION}

This study found a PCO incidence of $67 \%$ four years after loflex IOL surgery. This rate is higher than that reported for other hydrophilic lenses described in the literature. A better understanding of the pathogenic mechanisms of PCO is highly desirable as a basis for improving the outcome of cataract surgery and for eradicating this serious postsurgical complication.

\section{REFERENCES}

1. Johansson B. Clinical consequences of acrylic intraocular lens material and design: Nd:YAG-laser capsulotomy rates in $3 \times 300$ eyes 5 years after phacoemulsification. $\mathrm{Br}$ J Ophthalmol. 2010;94(4):450-5.

2. Auffarth GU, Brezin A, Caporossi A, Lafuma A, Mendicute J, Berdeaux G, Smith AF; European PCOStudy Group. Comparison of Nd:YAG capsulotomy rates following phacoemulsification with implantation of PMMA, silicone, or acrylic intraocular lenses in four European countries. Ophthalmic Epidemiol. 2004;11(4):319-29.

3. Senne FM, Temporini ER, Arieta CL, Pacheco KD. Perception of difficulties with vision-related activities of daily living among patients undergoing unilateral posterior capsulotomy. Clinics. 2010;65(5):459-68.

4. Apple DJ, Peng Q, Visessook N, Werner L, Pandey SK, Escobar-Gomez M, et al. Eradication of posterior capsule opacification: documentation. of a marked decrease in Nd:YAG laser posterior capsulotomy rates noted in an analysis of 5416 pseudophakic human eyes obtained postmortem. Ophthalmology. 2001;108(3):505-18. Comment in: Ophthalmology. 2002;109(4):625; author reply 625-6; Ophthalmology. 2002;109(4):626; author reply 626-7.

5. Hazra S, Palui H, Vemuganti GK. Comparison of design of intraocular lens versus the material for PCO prevention. Int JOphthalmol. 2012;5(1):59-63.

6. Kavoussi SC, Werner L, Fuller SR, Hill M, Burrow MK, Mclntyre JS, et al. Prevention of capsular bag opacification with a new hydrophilic acrylic disk-shaped intraocular lens. J Cataract Refract Surg. 2011;37(12):2194-200. Comment in: J Cataract refract Surg. 2012;38(5):924-5; author reply 925

7. BuehI W, Findl O. Effect of intraocular lens design on posterior capsule opacification. J Cataract Refract Surg. 2008;34(11):1976-85.

8. Leishman L, Werner L, Bodnar Z, Ollerton A, Michelson J, Schmutz M, et al. Prevention of capsular bag opacification with a modified hydrophilic acrylic disk-shaped intraocular lens. J Cataract Refract Surg. 2012:38(9):1664-70.

9. Tassignon MJ, Gobin L, Mathysen D, Van Looveren J, De Groot V. Clinical outcomes of cataract surgery after bag-in-the-lens intraocular lens implantation following ISO standard 11979-7:2006. J Cataract Refract Surg. 2011;37(12):2120-9.

10. Awasthi N, Guo S, Wagner B. Posterior capsular opacification: a problem reduced but not yet eradicated. Arch Ophthalmol. 2009:127(4):555-62.

11. Apple DJ, Werner L. Complications of cataract and refractive surgery: a clinicopathological documentation. Trans Am Ophthalmol Soc. 2001;99:95-107; discussion 107-9.

12. Apple DJ. Influence of intraocular lens material and design on postoperative intracapsular cellular reactivity. Trans Am Ophthalmol Soc. 2000;98:257-83.

13. Gauthier L, Lafuma A, Laurendeau C, Berdeaux G. Neodymium:YAG laser rates after bilateral implantation of hydrophobic or hydrophilic multifocal intraocular lenses: twenty-four month retrospective comparative study. J Cataract Refract Surg. 2010; 36(7):1195-200

14. Medeiros HA, Avila M, Santos PM. [Incidence of posterior capsule opacification in patients submitted to phacoemulsification and expandable acrylic intraocular lens implantation]. Arq Bras Oftalmol. 2006;69(4):371-5. Portuguese.

15. De Senne FM, Cardillo JA, Rocha EM, Kara-Jose N. Long-terns visual outcomes in the Cataract-Free Zone Project in Brazil. Acta Ophthalmol Scand. 2002;80(3):262-6.

16. Jorge PD, Jorge D, Ventura CV, Ventura BV, Lira W, Ventura MC, et al. Late opacification in hydrophilic acrylic intraocular lenses: Analysis of 87 eyes in a random sample of 102 patients. J Cataract Refract Surg. 2013;39(3):403-7.

17. Vasavada AR, Raj SM, Shah A, Shah G, Vasavada V, Vasavada V. Comparison of posterior capsule opacification with hydrophobic acrylic and hydrophilic acrylic intraocular lenses. J Cataract Refract Surg. 2011;37(6):1050-9.

18. Kugelberg M, Wejde G, Jayaram H, Zetterstroem C. Two-year follow-up of posterior capsule opacification after implantation of a hydrophilic or hydrophobic acrylic intraocular lens. Acta Ophthalmol. 2008;86(5):533-6.

19. Hayashi K, Hayashi H, Nakao F, Hayashi F. Changes in posterior capsule opacification after poly(methyl methacrylate), silicone, and acrylic intraocular lens implantation. J Cataract Refract Surg. 2001;27(6):817-24

20. Karahan E, Tuncer I, Zengin MO. The Effect of ND:YAG laser posterior capsulotomy size on refraction, intraocular pressure, and macular thickness. J Ophthalmol. 2014;2014: 846385. Epub 2014 Mar 3.

21. Burq MA, Taqui AM. Frequency of retinal detachment and other complications after neodymium:Yag laser capsulotomy. J Pak Med Assoc. 2008;58(10):550-2.

22. Billotte C, Berdeaux G. Adverse clinical consequences of neodymium:YAG laser treatment of posterior capsule opacification. J Cataract Refract Surg. 2004;30(10): 2064-71.

23. Chang A, Behndig A, Ronbeck M, Kugelberg M. Comparison of posterior capsule opacification and glistenings with 2 hydrophobic acrylic intraocular lenses: 5-to 7-year follow-up. J Cataract Refract Surg. 2013;39(5):694-8.

24. Maddula S, Werner L, Ness PJ, Davis D, Zaugg B, Stringham J, et al. Pathology of 157 human cadaver eyes with round-edged or modern square-edged silicone intraocular lenses: analyses of capsule bag opacification. J Cataract Refract Surg. 2011;37(4):740-8.

25. Werner L, Mamalis N, Pandey SK, Izak AM, Nilson CD, Davis BL, et al. Posterior capsule opacification in rabbit eyes implanted with hydrophilic acrylic intraocular lenses with enhanced square edge. J Cataract Refract Surg. 2004;30(11):2403-9.

26. Werner L, Tetz M, Feldmann I, Bucker M. Evaluating and defining the sharpness of intraocular lenses: microedge structure of commercially available square-edged hydrophilic intraocular lenses. J Cataract Refract Surg. 2009:35(3):556-66.

27. Vock L, Menapace R, Stifter E, Georgopoulos M, Sacu S, Buehl W. Posterior capsule opacification and neodymium:YAG laser capsulotomy rates with a round-edged silicone and a sharp-edged hydrophobic acrylic intraocular lens 10 years after surgery. J Cataract Refract Surg. 2009;35(3):459-65.

28. Pandey SK, Apple DJ, Werner L, Maloof AJ, Milverton EJ. Posterior capsule opacification: a review of the aetiopathogenesis, experimental and clinical studies and factors for prevention. Indian J Ophthalmol. 2004;52(2):99-112.

29. Ness PJ, Werner L, Maddula S, Davis D, Zaugg B, Stringham J, et al. Pathology of 219 human cadaver eyes with 1-piece or 3-piece hydrophobic acrylic intraocular lenses: Capsular bag opacification and sites of square-edged barrier breach. J Cataract Refract Surg. 2011;37(5):923-30

30. Vasavada AR, Praveen MR, Tassignon M-J, Shah SK, Vasavada VA, Vasavada VA, et al Posterior capsule management in congenital cataract surgery. J Cataract Refract Surg. 2011;37(1):173-93 